\title{
EEG theta and gamma responses to semantic violations in online sentence processing
}

\author{
Lea A. Hald ${ }^{\mathrm{a}, \mathrm{c}}$, Marcel C.M. Bastiaansen ${ }^{\mathrm{a}, \mathrm{b}, *}$, Peter Hagoort ${ }^{\mathrm{a}, \mathrm{b}}$ \\ ${ }^{a}$ Max Planck Institute for Psycholinguistics, P.O. Box 310, 6500 AH Nijmegen, The Netherlands \\ ${ }^{\mathrm{b}}$ F. C. Donders Centre for Cognitive Neuroimaging, Radbout Universiteit Nijmegen, P.O. Box 9101, 6500 HB Nijmegen, The Netherlands \\ ${ }^{\mathrm{c}}$ Center for Research in Language, University of California, San Diego, 9500 Gilman Dr., Dept. 0526, La Jolla, CA 92093-0526, USA
}

Accepted 18 June 2005

Available online 3 August 2005

\begin{abstract}
We explore the nature of the oscillatory dynamics in the EEG of subjects reading sentences that contain a semantic violation. More specifically, we examine whether increases in theta $(\approx 3-7 \mathrm{~Hz})$ and gamma (around $40 \mathrm{~Hz})$ band power occur in response to sentences that were either semantically correct or contained a semantically incongruent word (semantic violation). ERP results indicated a classical N400 effect. A wavelet-based time-frequency analysis revealed a theta band power increase during an interval of 300$800 \mathrm{~ms}$ after critical word onset, at temporal electrodes bilaterally for both sentence conditions, and over midfrontal areas for the semantic violations only. In the gamma frequency band, a predominantly frontal power increase was observed during the processing of correct sentences. This effect was absent following semantic violations. These results provide a characterization of the oscillatory brain dynamics, and notably of both theta and gamma oscillations, that occur during language comprehension.
\end{abstract}

(C) 2005 Elsevier Inc. All rights reserved.

Keywords: EEG oscillations; Gamma; Language processing; N400; Theta; Wavelets

\section{Introduction}

Currently, there has been a growing interest in the oscillatory dynamics that can be observed in the electrophysiological activity of the brain. Unlike Event-Related brain Potentials or fields (ERPs/ERFs; the so-called evoked activity) that can be extracted from the EEG or MEG by straightforward averaging of single trials, event-related changes in oscillatory EEG/MEG activity (termed induced activity) that speak on the synchronization and desynchronization aspect of neural activity have received little attention. The goal of the present study is to explore the oscillatory dynamics that coincide with the well-studied semantic ERP effect, the N400

\footnotetext{
* Corresponding author. Fax: +31243610989.

E-mail address: marcel.bastiaansen@fcdonders.kun.nl (M.C.M. Bastiaansen).
}

effect. We will focus on the modulation of oscillatory neuronal activity recorded in the EEG during the reading of sentences that contain either a semantically incongruent word (which elicits an N400 in the ERP analysis) or that are semantically congruent. More specifically, we want to establish whether semantic violations induce oscillatory activity that is qualitatively different from those induced by syntactic violations (which elicit a P600 in the ERP analysis) that have been found in a previous study (Bastiaansen, van Berkum, \& Hagoort, 2002b).

Much of the research on language comprehension has focused on the integration of semantic and syntactic information. In particular, a large body of research has centered on assessing the influence of semantic information on the syntactic analysis of sentences. This has spawned a debate about whether semantic and syntactic processing are subserved by neuronally distinct networks [i.e., as proposed by Hagoort and Brown (1999)] 
or whether semantics and syntax are processed by a single network [i.e., as proposed by McClelland, StJohn, and Taraban (1989)]. Within the domain of event-related potential (ERP) research, this debate has resulted in a search for ERP components that are differentially sensitive to semantic and syntactic processing in language comprehension. Several different ERP profiles appear to be related to either aspects of semantic or syntactic processing. Two in particular are the N400, which is related to semantic processing, and the P600, which is related to syntactic processing.

The P600 component is a broadly distributed positive shift that begins around $500 \mathrm{~ms}$ after the occurrence of a syntactic violation. The P600 has been observed with various syntactical violations, such as phrase structure violations, verb argument violations, and morpho-syntactic violations such as breaches of number and gender agreement (Friederici, Pfeifer, \& Hahne, 1993; Hagoort, Brown, \& Groothusen, 1993; Neville, Nicol, Barss, Forster, \& Garrett, 1991; Osterhout \& Mobley, 1995).

A seminal study by Kutas and Hillyard (1980) demonstrated that if participants are presented with sentences ending with a semantically inappropriate word (such as "He spread the warm bread with socks") vs. a contextually appropriate word, (for example, "He spread the warm bread with butter"), a significantly larger negativity in the ERP waveform occurs from 250 to $600 \mathrm{~ms}$ after the onset of the inappropriate word, with a peak amplitude around $400 \mathrm{~ms}$. Since Kutas and Hillyard (1980), a large body of research has utilized the N400 to investigate semantic processing. As a result of this research the N400 has been shown to occur to each and every word, but the amplitude and latency can be affected by a number of factors including word class, semantic relatedness to the context, cloze probability, ${ }_{1}$ word frequency, presentation modality, and verbal working memory load (Brown \& Hagoort, 1999; Kutas \& Van Petten, 1994, for reviews; see Chao, Nielsen-Bohlman, \& Knight, 1995; Neville, Kutas, Chesney, \& Schmidt, 1986; Smith, Stapleton, \& Halgren, 1986; Stuss, Picton, \& Cerri, 1986; for examples of N400 effects related to working memory). In general, a larger amplitude N400 will be found to a word that is not related to the context, has a low cloze probability or a low frequency. The N400 effect has been interpreted as reflecting some aspect(s) of the processes that integrate the meaning of a particular word into a higher-order semantic representation (Brown \& Hagoort, 1999; Osterhout \& Holcomb, 1992; Rugg, 1990; however see Kutas \& Van Petten, 1994; for an alternative suggestion).

\footnotetext{
${ }^{1}$ The cloze probability test requires subjects to complete sentence fragments, and the "cloze probability" of a word refers to the proportion of subjects who completed a particular sentence fragment with that particular word (Taylor, 1953).
}

To form a full understanding of language input all of the different parts of information that are processed in different brain areas must be integrated. How this binding between the distributed nodes of the language network is implemented still an open question, but it has been suggested that it may be propagated by synchronization and desynchronization of oscillatory neural activity. In this view, synchronization and desynchronization link spatially distributed brain areas together to form transient functional networks (Singer, 1993, 1999).

It is generally agreed upon that analyzing eventrelated changes in either amplitude, or (phase) coherence of EEG oscillations provide a window onto the processes of synchronization and desynchronization of neuronal populations (Tallon-Baudry \& Bertrand, 1999; Varela, Lachaux, Rodriguez, \& Martinerie, 2001). Two types of increase are studied: an increase in amplitude of oscillatory EEG activity is taken to at least partially reflect an increase in synchrony of the underlying local neuronal population. On the other hand, an increase in (phase) coherence between EEG sensors is thought to reflect increased synchrony between spatially distributed neuronal populations. These event-related increases in synchrony in turn are considered to reflect the transient formation of local and spatially distributed functional networks (for review, see Varela et al., 2001).

Oscillatory dynamics cannot be studied with standard ERP methodology. The reason for this is that although event-related changes in amplitude of a given oscillation may be time-locked to an experimental event, the phase of the activity at a given point in time will differ from trial to trial. As a result, oscillations largely cancel out during the averaging process that is used in ERP analysis (see Bastiaansen \& Hagoort, 2003; Tallon-Baudry, Bertrand, Delpuech, \& Pernier, 1996; for a more detailed account of the signal-analytic distinction between ERPs and event-related oscillatory activity). For a proper analysis of oscillatory dynamics, different analytic tools have to be used such as wavelet-based time-frequency analysis (for quantifying amplitude changes) or eventrelated coherence analysis (for quantifying changes in phase coherence between electrodes; for a further review, see Bastiaansen \& Hagoort, 2003). Recent studies employing such techniques have clearly demonstrated that synchronous oscillations have functional significance during the execution of tasks engaging a variety of cognitive operations, such as memory encoding and retrieval (e.g., Burgess \& Ali, 2002; Fell et al., 2001; Klimesch, 1999), working memory (e.g., Jensen \& Tesche, 2002; Kahana, Sekuler, Caplan, Kirschen, \& Madsen, 1999; Tesche \& Karhu, 2000), face perception (Rodriguez et al., 1999), object detection (Tallon-Baudry $\&$ Bertrand, 1999), and attentional processes (e.g., Bastiaansen \& Brunia, 2001; Foxe, Simpson, \& Ahlfors, 1998; Fries, Reynolds, Rorie, \& Desimone, 2001; Klimesch, 1999). Recently, such studies are also being performed in 
the domain of language comprehension (e.g., Bastiaansen, van Berkum, \& Hagoort, 2002a; Bastiaansen et al., 2002b; Bastiaansen, Van der Linden, ter Keurs, Dijkstra, \& Hagoort, 2005; Pulvermüller, Lutzenberger, \& Preissl, 1999; Schack, Weiss, \& Rappelsberger, 2003; Weiss \& Rappelsberger, 1996; Weiss, Müller, King, Kutas, \& Rappelsberger, 2001; Weiss, Müller, \& Rappelsberger, 2000; see also the review in Weiss \& Müller, 2003). Still, relatively little is known about synchronous oscillations and their possible functions during language comprehension.

In our previous studies we characterized the time course of event-related amplitude modulations in oscillatory activity in the theta $(4-7 \mathrm{~Hz})$, alpha $(8-12 \mathrm{~Hz})$, and beta $(>13-30 \mathrm{~Hz})$ frequency bands during the processing of correct sentences (Bastiaansen et al., 2002a), of sentences containing syntactic violations, which elicited a P600 in the ERP analysis (Bastiaansen et al., 2002b), and of open-class words vs. closed-class words occurring within a sentence context (Bastiaansen et al., 2005). In all three studies, event-related power changes in the theta frequency range showed a marked reactivity to the various linguistic manipulations, suggesting a functional role for theta band activity during language processing. The general pattern of results that has emerged from these studies is that theta increases can be observed over left occipital areas, bilaterally over the temporal cortex, and over frontocentral regions. The left occipital theta response has been related to the encoding of the visual word form. The (left) temporal theta response has been associated either with lexico-semantic retrieval (Bastiaansen et al., 2005) or with increased verbal working memory load (Bastiaansen et al., 2002a). The frontocentral theta increase is more difficult to characterize in functional terms: it increases with working memory load (Bastiaansen et al., 2002a) is present after both openclass and closed-class words (Bastiaansen et al., 2005), and was found to increase following syntactic violations. In addition, different types of syntactic violations led to a different lateralization of the frontal theta increase, a result that we will return to in the discussion (Bastiaansen et al., 2002b).

The principal aim of the present study is to explore the oscillatory dynamics of the EEG recorded during sentences that are either semantically coherent or have a semantic violation. Characterizing the oscillatory dynamics during semantic violations will yield additional information on the neural mechanisms underlying the processing of semantic information.

\section{Methods}

\subsection{Participants}

Thirty-nine native speakers of Dutch participated in the experiment, 30 of which were included in the final analysis (24 females, 6 males; aged 18-28). They were paid a small fee for their participation. All subjects had normal or corrected-to-normal vision, normal hearing, and all were right handed. Seven of the participants included in the analysis reported having left-handed relatives. None of the subjects had any neurological impairment nor had any of the subjects participated in the pretest (see below). Nine of the participants that participated were excluded from the final analysis due to excess eye-movement (see EEG Recording and Analysis below).

\subsection{Stimulus material}

One hundred and twenty pairs of sentences were included in the critical item set. Each pair of sentences was identical with the exception of one word (critical word, CW, in capital letters in the examples below). Each pair consisted of a sentence that was semantically coherent (correct condition), and a sentence that contained a semantic violation (violation condition). A written questionnaire pretest (described below) was used to establish the soundness of the semantic violation.

(1) Correct sentence: De Nederlandse treinen zijn GEEL en blauw. (The Dutch trains are YELLOW and blue.)

(2) Semantic violation: De Nederlandse treinen zijn ZUUR en blauw (The Dutch trains are SOUR and blue.)

The critical words were matched across conditions on the following criteria: (1) average length in characters (correct: 6.4; violation: 6.3); (2) word frequency (correct: 3.2; violation: 3.0, based on log lemma frequencies; Baayen, Piepenbrock, \& van Rijn, 1993); (3) word class (equated within each pair). None of the critical words were over 10 letters in length, nor did they appear as the sentence final word. Sentences varied in length from 7 to 13 words, with the average sentence length being 10.1 words long. The average sentence presentation duration was $5.78 \mathrm{~s}(S D=1.03 \mathrm{~s})$.

The 120 pairs were pseudorandomized across three different lists so that each subject only read one of the sentences in each of the pairs. Each subject saw only one list, which contained 40 exemplars of each of the two conditions. These 80 critical items per list were then mixed with 80 unrelated filler items, half of which also contained a semantic violation and half were correct sentences of similar length and complexity. The experiment was split into three blocks, two of which had 56 trials and one with 57 trials. In addition, there was a practice block of 18 items and nine extra starter items, which were similar in nature to the experimental items. These starter items were used three at a time at the start of each experimental block to minimize loss of data due to artifacts after beginning a new block. Following each block there was a short break. 


\subsection{Pretest}

Sixteen native speakers of Dutch (who did not participate in the subsequent EEG experiment) completed the cloze pretest. The pretest was done to assess the cloze probability of the critical words. For each sentence pair, one sentence that stopped just prior to the critical word was given and the subjects were required to complete each sentence (e.g., "De Nederlandse treinen zijn ."; "The Dutch trains are__."). The results of this paper and pencil pretest revealed that the cloze probability for the CW's in the correct sentence was $49 \%$ (range $0-100 \%$ ) and in the semantic violation condition $0 \%$ (range $0 \%$ ).

\subsection{Procedure}

For the EEG experiment, subjects were tested in a dimly lit, sound-attenuating booth. They were seated in a comfortable reclining chair. Subjects were asked to attentively read the sentences and try to understand them as well as possible. No other task demands were imposed. At the end of the experiment, a short questionnaire was verbally administered to the participants to determine if they realized the experimental manipulation and to obtain comments about the experimental materials, as well as the experiment as a whole.

Each trial was presented word by word in white lowercase Arial letters (18-point font size). The first word of each sentence was capitalized and the final word of each sentence was presented with a period. The letters were displayed against a dark background in the center of a VGA computer screen. Viewing distance was $\approx 110 \mathrm{~cm}$, and the largest word subtended a visual angle of about $3.2^{\circ}$ horizontally and $0.5^{\circ}$ vertically. Each word was presented for $300 \mathrm{~ms}$, followed by a blank screen for $300 \mathrm{~ms}$ that was followed by the next word. After the final word there was a blank screen for $600 \mathrm{~ms}$ that was followed by an asterisk displayed in the middle of the screen for $3000 \mathrm{~ms}$, indicating to the subjects that they could blink and move their eyes. There was a $300 \mathrm{~ms}$ delay between the asterisk disappearing and the start of the next trial.

\subsection{EEG recording and analysis}

The EEG was recorded from $29 \mathrm{Ag} / \mathrm{AgCl}$-sintered electrodes mounted in a cap, each referred to the left mastoid. Five electrodes were placed according to the 10\%-standard system of the American Electroencephalographic Society over midline sites at $\mathrm{Fz}, \mathrm{FCz}, \mathrm{Cz}, \mathrm{Pz}$, and $\mathrm{Oz}$ locations, along with nine lateral pairs of electrodes over standard sites on frontal (AF3, AF4, F3, F4, $\mathrm{F} 7$, and F8), fronto-central (FC3 and FC4), fronto-temporal (FT7 and FT8), central (C3 and C4), centro-parietal (CP3 and CP4), parietal (P3 and P4), and occipital (PO7 and PO8) positions. Three additional pairs were
Electrode setup

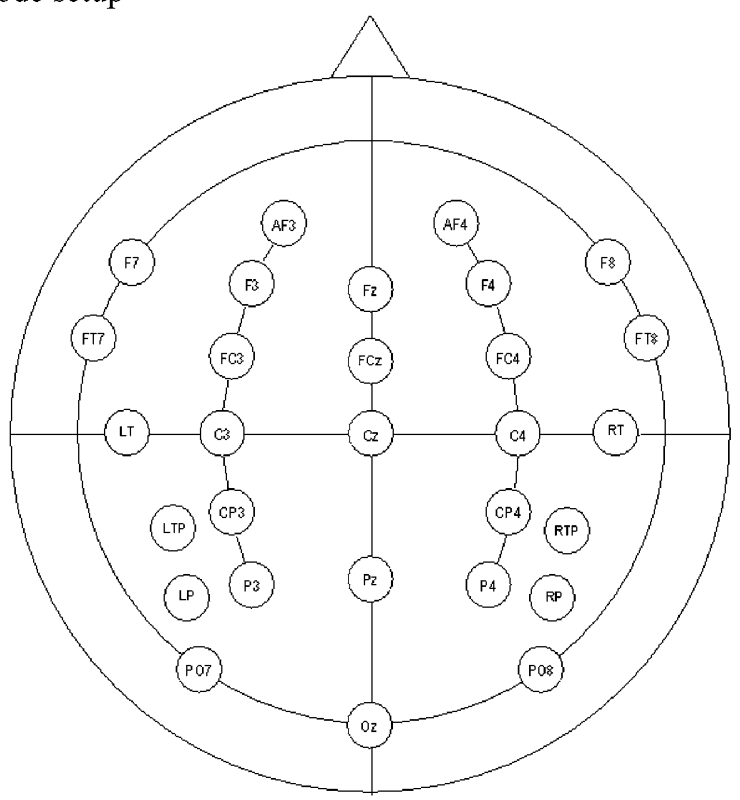

Fig. 1. Radial projection of electrode positions and corresponding labels.

placed laterally over symmetrical positions: (a) a temporal pair (LT and RT) placed laterally to $\mathrm{Cz}$, at $33 \%$ of the interaural distance, (b) a temporo-parietal pair (LTP and RTP) placed $30 \%$ of the interaural distance lateral and $13 \%$ of the nasion-inion distance posterior to $\mathrm{Cz}$, and (c) a parietal pair midway between LTP/RTP and PO7/PO8 (LP and RP). Note that we also refer to electrodes as channels, which is a convention in the oscillatory analysis literature.

Fig. 1 presents electrode setup and labels. Vertical eye movements were monitored via a supra- to sub-orbital bipolar montage. A right to left canthal bipolar montage was used to monitor for horizontal eye movements. Activity over the right mastoid bone was recorded on an additional channel to determine if there were differential contributions of the experimental variables to the presumably neutral mastoid site. No such differential effects were observed.

The EEG and EOG recordings were amplified with a SynAmp Model 5083 EEG amplifier (NeuroScan Inc., Herndon, Va, USA), using a hi-cut of $70 \mathrm{~Hz}$ and a time constant of $8 \mathrm{~s}(0.02 \mathrm{~Hz})$. Electrode impedances were kept below $3 \mathrm{k} \Omega$ for the EEG recording and below $5 \mathrm{k} \Omega$ for the EOG recording. The EEG and EOG signals were digitized online with a sampling frequency of $500 \mathrm{~Hz}$.

The EEG data were screened for eye movements, electrode drifting, amplifier blocking, and EMG artifacts in a critical window ranging from $150 \mathrm{~ms}$ before to $1800 \mathrm{~ms}$ after the onset of the critical word. Trials containing such artifacts were rejected $(10.7 \%$ overall). Nine subjects were excluded from the final analysis because more than $20 \%$ of the trials were rejected. Thus, 30 subjects remained for subsequent analysis. 


\subsection{ERP analysis}

For each subject, average waveforms were computed across all trials per condition, using a $150 \mathrm{~ms}$ pre-CW baseline. The N400 was quantified as the mean amplitude in a latency window of $300-550 \mathrm{~ms}$ after $\mathrm{CW}$ onset. A late positivity was observed in the semantic violation condition (see Fig. 2). This positivity was quantified as the mean amplitude in a latency window of $800-1200 \mathrm{~ms}$ after $\mathrm{CW}$ onset.

For a statistical evaluation of the ERP effects an overall ANOVA was performed. Additionally, we defined four regions of interest by averaging the data from single electrodes: left anterior (LAnt: AF3, F7, F3, FT7, FC3); right anterior (RAnt: AF4, F4, F8, FC4, FT8), left posterior (LPos: CP3, LTP, LP, P3, PO7), and right poster-
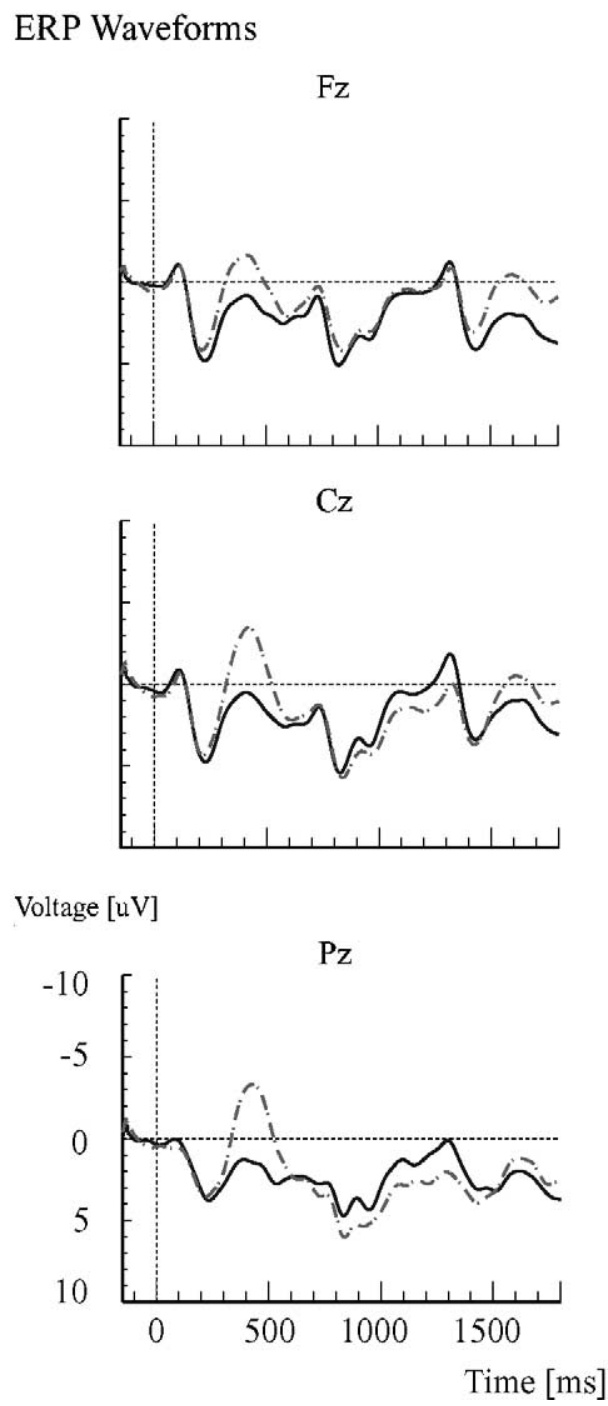

Fig. 2. ERP waveforms at selected electrode positions for the correct condition (solid line) and the semantic violation condition (broken line). The time $0 \mathrm{~ms}$ marks the critical word onset. Note the classic N400 effect, showing up as a surplus negativity between roughly 200 and $600 \mathrm{~ms}$ after word onset. ior (CP4, RTP, P4, RP, PO8). An ANOVA for repeated measures was performed for the N400 and for the late positivity separately. Factors were Condition (Correct, Violation), Hemisphere (Left, Right), and Anteriority (Anterior, Posterior). Significant interactions were clarified by breaking them down into simple effects.

\subsection{Time-frequency analysis}

To isolate the induced-type oscillations (non-phase locked) from the (evoked-type) ERP components (cf. Bullock, 1992; Tallon-Baudry \& Bertrand, 1999; for descriptions of this distinction), we computed, for every subject, the average ERP, and subtracted this average from each single trial. This was done separately for the two conditions (see e.g., Kalcher \& Pfurtscheller, 1995; Klimesch, Russegger, Doppelmayr, \& Pachinger, 1998; for a similar approach).

Time-frequency (TF) representations of the single trial data were then obtained by computing the squared norm of the result of the convolution of complex Morlet wavelets with the EEG data, as described by TallonBaudry et al. (1996). We used wavelets with a 7-cycle width, with frequencies ranging from 1 to $70 \mathrm{~Hz}$, in $1 \mathrm{~Hz}$ steps. TF representations were then averaged over trials for each subject, separately for the two conditions. The average power values (i.e., squared amplitude) thus obtained were expressed as a percentage change relative to the power in a baseline interval from -150 to $0 \mathrm{~ms}$ prior to word onset, to normalize for individual differences in EEG power, and for differences in absolute power between different frequency bands.

For an exploratory statistical analysis of the modulation of power changes as a function of experimental condition, we used an adapted version of the randomization procedure proposed by Maris (2004), with a cluster growing approach that corrects for multiple comparisons. Note that for practical reasons, the time-frequency window for this analysis was restricted from 1 to $50 \mathrm{~Hz}$, and from 0 to $700 \mathrm{~ms}$ post-stimulus. The following steps were performed: we created 1000 grand-average randomizations of the TF representations of both the correct control (CC) and the semantic violation (SV) conditions by a random permutation, and subsequent averaging, of $\mathrm{CC}$ and SV TF representations of individual subjects' EEG data. For each of the randomizations the grand-average $\mathrm{CC}$ was subtracted from the grand-average SV. This results in a distribution of the difference between $\mathrm{CC}$ and SV for each 'pixel' of the TF representation. For each randomization and each pixel, the significance of the SV$\mathrm{CC}$ difference was computed by comparing the observed difference in that specific randomization to the distribution of all randomizations, resulting in a probability ( $p$ value) for each pixel in each randomization.

The complete TF representation with the probabilities of all pixels was thresholded at a $1 \%$ significance 
level (two-sided). Clusters of spatially contiguous pixels (in three dimensions, i.e., time, frequency, and channels) were then identified. The sum of the $t$ statistics of all the pixels in such a cluster was subsequently used as the cluster-level test statistic. To correct for multiple comparisons, for each of the 1000 randomizations the largest cluster-level test statistic was used to create a null distribution of the cluster-level statistic. Then, the cluster-level test statistic was computed for the actually observed grand-average data and compared against the null distribution. Clusters with a statistic falling in the highest or lowest 2.5 th percentile were considered significant.

\section{Results}

\subsection{ERP analysis}

Grand-average ERPs for both conditions are presented in Fig. 2 for a selected number of electrodes. Furthermore, scalp topographies for the N400 are given in Fig. 3 for both conditions.

\subsubsection{N400}

The overall ANOVA for data within the time window $300-550 \mathrm{~ms}$ indicated that words constituting a semantic violation evoked a larger negative-going deflection (N400) than their correct counterparts (mean $-0.63 \mu \mathrm{V}$, standard error ( $S E$.) 0.24 vs. mean $1.52 \mu \mathrm{V}, S E 0.25$ ), respectively; main effect of Condition: $F(1,29)=75.58$, $M S e=18.57, p<.001$. An interaction of Condition and Anteriority $(F(1,29)=8.99, p=.006)$ further indicated that the effect of Condition was largest at posterior electrodes (mean $-0.76 \mu \mathrm{V}, S E 0.33$ for violations, $1.89 \mu \mathrm{V}$, $S E \quad 0.28$ for correct sentences; $F(1,29)=69.70$, $M S e=15.07 p<.001)$. However, it was also significant at anterior sites (mean $-0.51 \mu \mathrm{V}, S E 0.26$ vs. $1.14 \mu \mathrm{V}, S E$ 0.26, respectively; $F(1,29)=35.60, \quad M S e=11.54$, $p<.001)$. There was no significant difference between the left and right hemispheres.

\subsubsection{Late positivity}

The late positivity (time window $800-1200 \mathrm{~ms}$ ) showed no main effect of condition, $(F(1,29)=0.928, M S e=37.50$, $p=.34)$. However, an interaction of Condition and Anteriority $(F(1,29)=8.00, M S e=15.46, p=.008)$ indicated a significant effect of Condition at posterior sites (correct: mean $2.56 \mu \mathrm{V}, S E 0.30$, violation: mean $3.55 \mu \mathrm{V}, S E 0.45$; $F(1,29)=5.97, M S e=24.27, p=.021)$, but not at anterior sites (correct: mean $2.21 \mu \mathrm{V}, S E 0.31$, violation: mean 1.91, $S E 0.34, \mu \mathrm{V}, F(1,29)=0.475, M S e=28.69, p=.496)$. The positivity of the violation was maximal over the right posterior electrodes (left posterior violation: mean $3.08 \mu \mathrm{V}$, $S E 0.47$, right posterior violation: mean $4.01 \mu \mathrm{V}, S E 0.47$; $F(1,29)=15.90, M S e=4.02, p<.001)$.

\subsection{Time-frequency analysis}

Fig. 4 presents TF representations of the power changes in both conditions, at selected electrodes.

\subsubsection{Randomization statistics}

The randomization analysis (see Fig. 5) revealed two significant clusters in the TF representation of the power changes. One positive cluster $(p=.048)$, indicating a larger power increase for the semantic violation condition compared to the correct sentence condition, was present in the theta frequency range. Depending on the exact channel, the onset of the effect ranged from 250 to $600 \mathrm{~ms}$, and the offset from 600 to $700 \mathrm{~ms}$ (which is the end of the analyzed time range), and the frequency range was from 3 to $5 \mathrm{~Hz}$. A second, negative cluster $(p=.034)$ indicated a larger power increase in the gamma frequency range $(35-45 \mathrm{~Hz}$ for most channels) for the correct sentence condition compared to the semantic violation condition. Although Fig. 4 clearly shows a series of

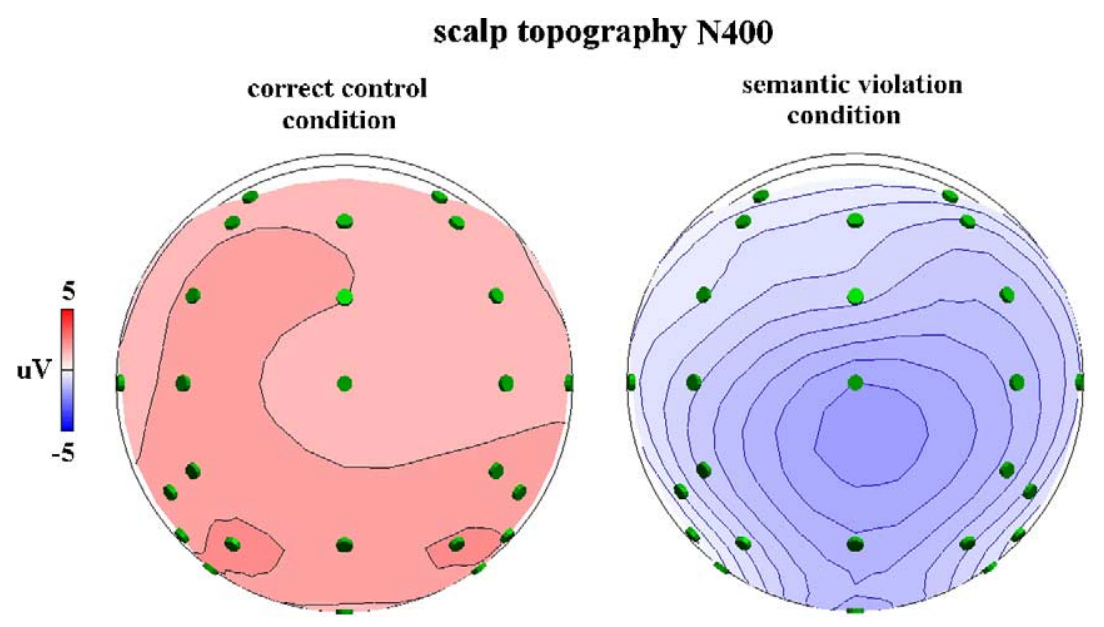

Fig. 3. Scalp topography of the N400 for the correct condition and the semantic violation condition, in the time interval between 300 and $550 \mathrm{~ms}$ after word onset. 
correct sentence condition
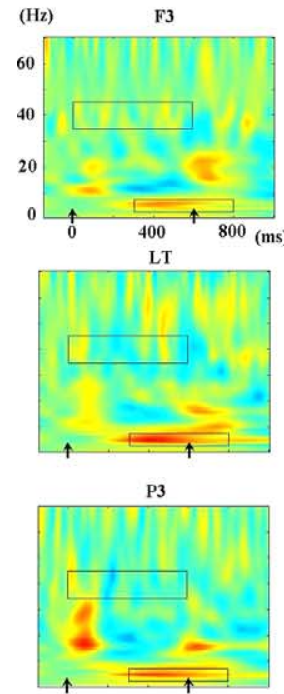

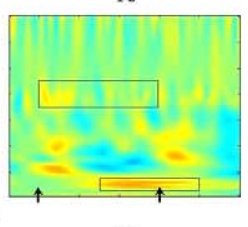

$\mathrm{Cz}$
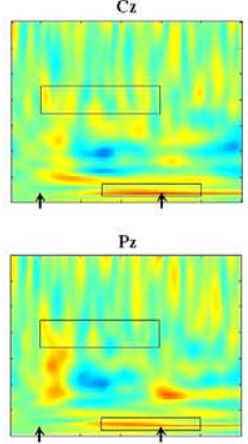

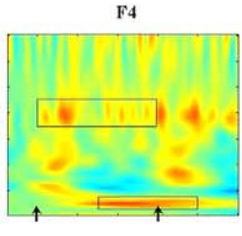

RT

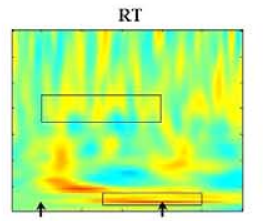

P4

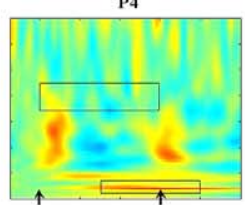

semantic violation condition
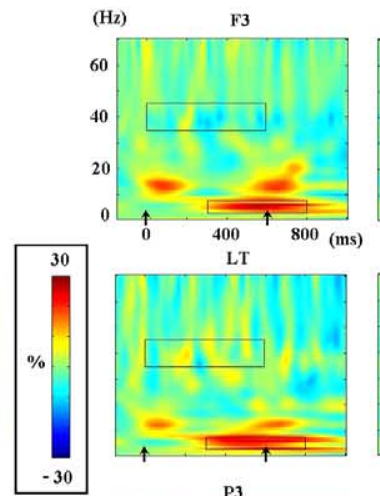

P3
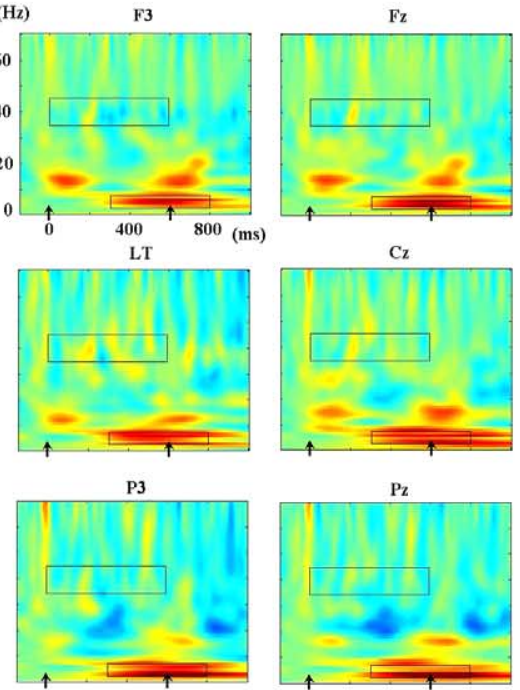

$\mathrm{Cz}$

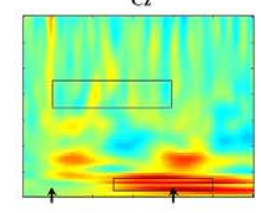

$\mathrm{P}_{\mathbf{Z}}$

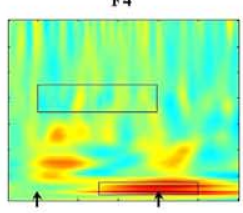

RT
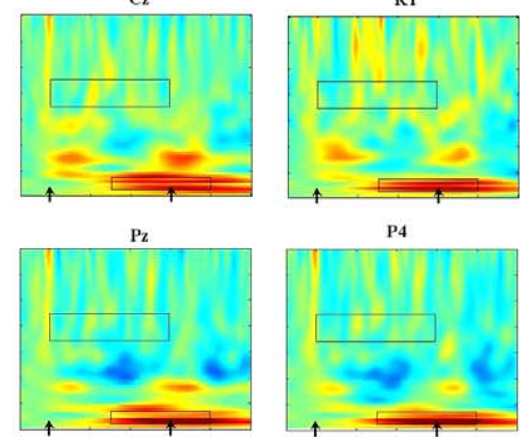

Fig. 4. Time-Frequency (TF) representations of the power changes in both conditions. TF plots are given for representative channels, with blue representing power decreases and red depicting power increases. Black rectangles in the TFRs indicate the time-frequency intervals used for the topographic plots of theta and gamma, shown in Figs. 6 and 7 (see text for details).

$\mathbf{A}$

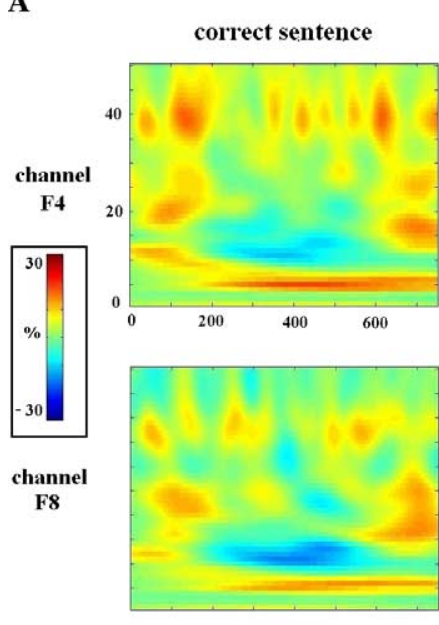

$\mathbf{B}$

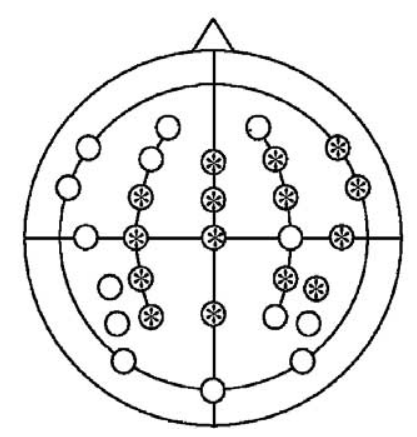

significant channels:

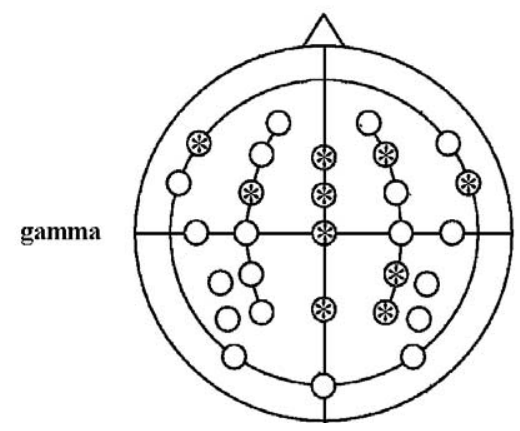

Fig. 5. Graphical representation of the results of the randomization analysis. (A) For two representative electrodes, TF representations are shown for the correct sentence and the semantic violation condition. Then a TF plot of the difference (violation - correct) is given, and finally this TF plot is masked to only show those power changes that are significant in the randomization analysis. (B) Radial projection of the electrode montage, showing with asterisks those electrodes that are part of the significant theta cluster (left-hand map) or of the significant gamma cluster (right-hand map). 
successive gamma bursts in the correct sentence condition (e.g., at channel F4), only the first such burst, roughly from 50 to $200 \mathrm{~ms}$ post-stimulus, reached significance in this analysis. Fig. 5A depicts the results of the randomization analysis for two representative electrodes; Fig. 5B shows a topographic representation of the electrodes at which each of the clusters reached significance.

To assess how the changes in theta and gamma power behave over subjects, the distribution of theta and gamma effects across individual subjects are shown in Fig. 6, pooled for those electrodes that participate in the respective clusters. The time-frequency intervals used to estimate the individual subject theta and gamma changes are the same as those used for the topographic plots in Figs. 7 and 8, i.e., $300-800 \mathrm{~ms}$ post-stimulus, $3-7 \mathrm{~Hz}$ for theta, and $0-600 \mathrm{~ms}, 35-45 \mathrm{~Hz}$ for gamma.

\subsubsection{Scalp topographies of theta and gamma power changes relative to baseline}

The randomization analysis shows that significant differences between the two conditions exist only in the theta and the gamma frequency ranges. However, this analysis exclusively tests for significant differences between the two experimental conditions. Given that in previous studies (Bastiaansen et al., 2002a, 2002b, 2005) we found localized foci of (theta) power increases relative to baseline, the next step in the data analysis was to characterize, for each condition, the scalp topographies of the theta and gamma power changes relative to the pre-stimulus baseline. To optimally characterize these scalp topographies, time-frequency intervals were selected around the locations where the theta and gamma power increases were maximal, on the basis of a visual inspection of the TF representations (see Fig. 4 and the black rectangles therein). For the theta component this was $3-7 \mathrm{~Hz}$, and $300-800 \mathrm{~ms}$ post-stimulus. For the gamma component, we identified a series of successive bursts from 0 to $600 \mathrm{~ms}$ post-stimulus, in a frequency range of $35-45 \mathrm{~Hz}$. The resulting scalp topographies are given in Figs. 7 (theta) and 8 (gamma).

The theta scalp topographies in Fig. 7 show bilateral temporal theta foci in both conditions. In addition, a
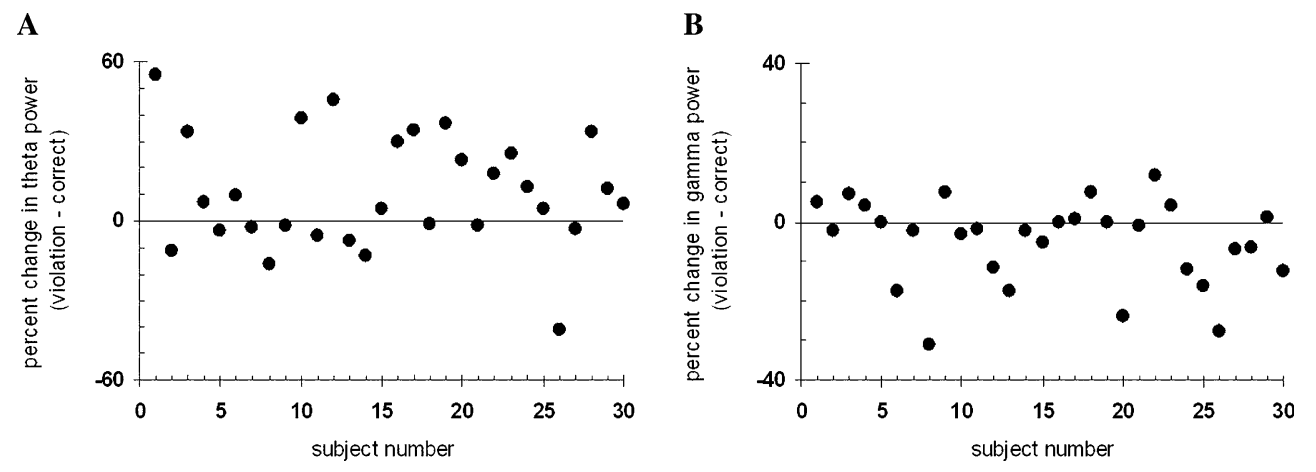

Fig. 6. Distribution of theta (A) and gamma (B) effects (that is, the difference between the violation and the correct sentence conditions) across individual subjects, pooled for those electrodes that participate in the respective clusters resulting from the randomization analysis (see Fig. 5B). The time-frequency intervals used to estimate the individual subject theta and gamma changes are the same as those used for the topographic plots in Figs. 7 and 8, i.e., $300-800 \mathrm{~ms}$ post-stimulus, $3-7 \mathrm{~Hz}$ for theta, and $0-600 \mathrm{~ms}$ post-stimulus, $35-45 \mathrm{~Hz}$ for gamma.

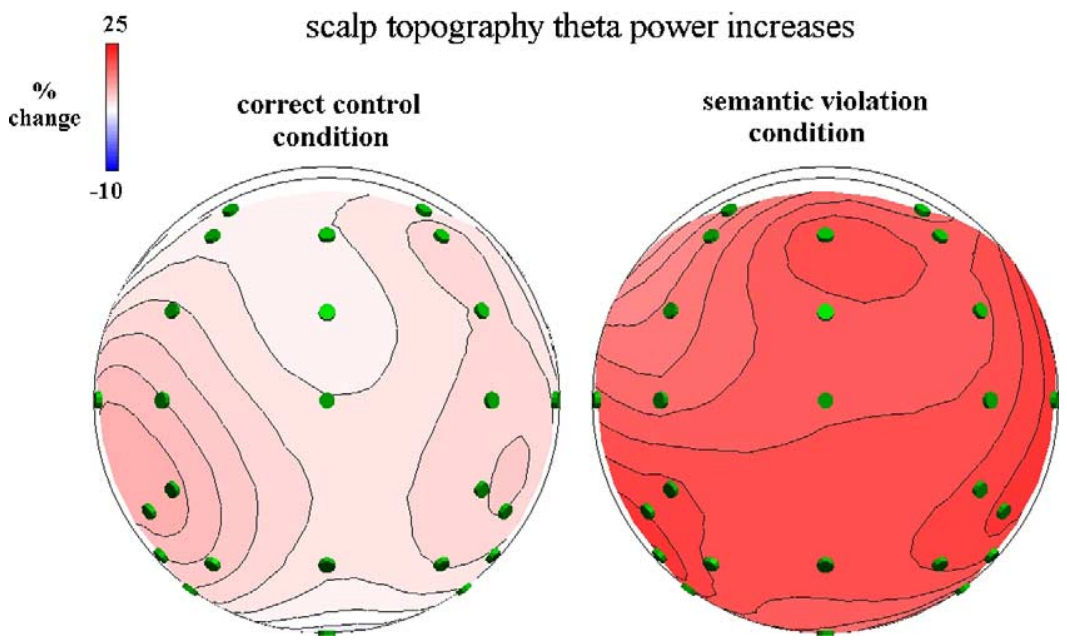

Fig. 7. Scalp topography of the theta power changes (from 3 to $7 \mathrm{~Hz}$ ) in the correct condition and the semantic violation condition, averaged over a time interval from 300 to $800 \mathrm{~ms}$ after word onset. Spacing of contour lines is $1.8 \%$. 

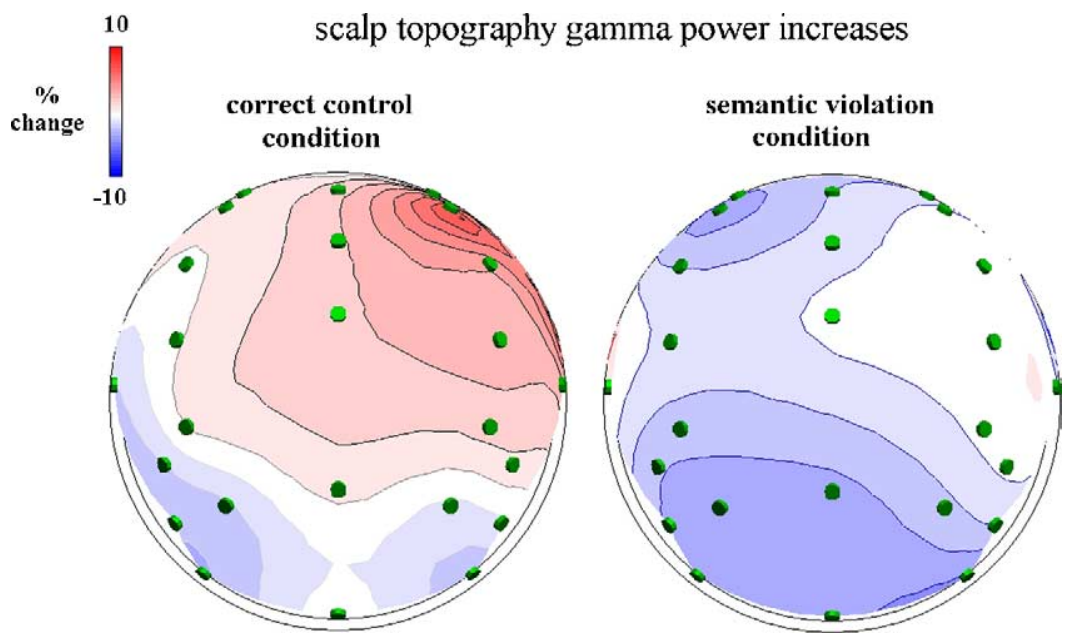

Fig. 8. Scalp topography of the gamma power changes (from 35 to $45 \mathrm{~Hz}$ ) in the correct condition and the semantic violation condition, averaged over a time interval from 0 to $600 \mathrm{~ms}$ after word onset. Spacing of contour lines is $1.4 \%$.

striking effect is the presence of a theta peak over the frontocentral midline in the semantic violation condition, as opposed to the correct sentence condition. This qualitative difference was substantiated statistically in the following post hoc analysis: for each subject, we computed the average theta power change from 300 to $800 \mathrm{~ms}$ post-stimulus, and $3-7 \mathrm{~Hz}$ both for the peak (electrode $\mathrm{Fz}$ ), and for the average of the surrounding electrodes (i.e., AF3, AF4, F3, F4, and FCz). Then, we subtracted the average power change at the surround from the peak, for each subject. For both conditions, a single-sample $t$ test then verified whether this difference was significantly different from zero. For the correct sentence condition, this was not the case, indicating the absence of a peak at $\mathrm{Fz}$ for this condition (a difference of $-0.20 \%$ change; $t_{29}=-0.276, M S e=0.710, p=.784$ ). For the semantic violation condition this difference was significant $\left(2.66 \%\right.$ change; $t_{29}=3.353, M S e=0.793$, $p=.002$ ), which indicates the existence of a peak theta power increase at $\mathrm{Fz}$ for this condition. Furthermore, the difference between $\mathrm{Fz}$ and its surrounding electrodes was significantly different between the conditions, as indicated by a paired-sample $t$ test $\left(2.85 \%\right.$ change; $t_{29}=2.97$, $M S e=0.961, p=.006$ ). Thus, this post hoc analysis confirms the notion of a qualitative difference in theta responses between the correct and semantic violation conditions, in that only the violation condition shows a peak theta increase over the midfrontal scalp.

\section{Discussion}

An EEG experiment was performed in which subjects read either correct Dutch sentences, or sentences that contained a semantic violation. Event-related potentials (ERPs) and oscillatory brain dynamics were studied. The principal aim of the experiment was to characterize the nature, i.e., magnitude and scalp topography, of EEG power (i.e., squared amplitude) changes that were expected to occur as a result of the semantic violations.

The ERP analyses of the EEG data showed a typical pattern of results, namely a larger amplitude N400 for semantically incongruent words than for otherwise comparable words that were semantically congruent. Additionally, a late positive deflection that was larger following violations than following correct words was found. The wavelet-based time-frequency (TF) analysis revealed that event-related power changes in the theta frequency band were larger following semantic violations than following correct sentence continuations over a large number of electrodes. Furthermore, an additional peak of theta power was present at electrode $\mathrm{Fz}$ in the violation condition only. In the gamma frequency band (here $35-45 \mathrm{~Hz}$ ), power was larger in the correct sentence condition than following semantic violations over a large number of electrodes. Relative to baseline gamma oscillations showed up during the processing of correct sentences as a series of successive bursts between 0 and $600 \mathrm{~ms}$, with a right frontal maximum in the scalp distribution.

As a first remark, it should be noted that none of the time-frequency components has a scalp topography that is comparable to the ERP components (compare Fig. 3 with Figs. 7 and 8). As we mentioned in the introduction, this underlines that the different analysis procedures indeed zoom in on different aspects of neural activity, although the functional differences between ERPs and event-related oscillatory brain dynamics are only poorly understood at present.

\subsection{Theta power changes}

The power changes in the theta frequency range show both quantitative and qualitative differences between the 
experimental conditions. The most obvious effect (see Figs. 5 and 7) is that theta increases are larger following a semantically incongruent word than following a semantically congruent word. The topographic distribution of the theta power changes, with maxima at bilateral temporal electrodes for both conditions and an additional peak over midfrontal areas that is restricted to the semantic violation condition, hints at the existence of multiple neural generators that may differ in terms of their functional relevance for language processing. One aspect of the topographical distribution that is notable is that unlike the results of our previous study (Bastiaansen et al., 2005), where increases in theta were observed over left occipital areas, here we did not see that occipital theta response. We tentatively hypothesized that the left occipital theta response is related to the encoding of the visual word form,. However, if that were the case it is unclear why we would not see that effect in the current study. Further, investigation into the relationship between the previously observed occipital theta response and language comprehension is necessary to better understand what this response is related to in processing terms. Regarding the distribution of the theta power changes that we did find, let us first consider the theta increase at temporal electrode sites.

Theta increases at temporal electrode sites prove to be a robust finding, since they have been observed repeatedly. At temporal electrode sites theta was found to increase in magnitude during the course of processing correct Dutch sentences (Bastiaansen et al., 2002a), and it was observed (albeit only over the left hemisphere) during the processing of open-class words occurring in a sentence context (Bastiaansen et al., 2005). Since in the latter study the temporal theta increase was found to be absent following closed-class words (which have little semantic value), this component has been tentatively related to lexico-semantic retrieval (Bastiaansen et al., 2005). This interpretation fits the observation that theta power increases are related to retrieval processes (Klimesch et al., 2001). Note that in the latter study (as in a range of other studies relating theta to memory encoding and/or retrieval, reviewed in Klimesch, 1999), theta power changes showed a widespread distribution. The current finding of topographic peaks over the left (and sometimes also right) temporal cortex therefore suggests that a lexico-semantic retrieval process may have a more focal distribution.

The midfrontal theta increase in the present data was found only after words constituting a semantic violation, and thus represents a qualitative difference between the two experimental conditions. Interestingly, this theta increase was also distinctly different than the theta power increases that we have previously observed for syntactic violations, which elicited a P600 in the ERP analysis. In our previous study (Bastiaansen et al., 2002b), syntactic number violations elicited a theta power increase with a left frontal maximum and syntactic gender violations elicited a theta power increase with a maximum in the right frontal electrodes. Given that each violation type (syntactic number, syntactic gender, and semantic) led to differential frontal theta increases, it is tempting to relate this effect to specific differences in processing semantic information and syntactic information. However, alternative interpretations are equally viable. For instance, the previously observed syntactic violation effects (Bastiaansen et al., 2002b) may be due to an increase in verbal working memory (WM) load caused by the necessity to re-analyze the sentence. In a similar vein, the present frontal theta effect could be argued to reflect an increase in verbal WM load due to the fact that the subject has to evaluate online whether the presented word can be successfully integrated into the sentence context. Although this is only a tentative hypothesis, it does gain some support from similar frontal theta effects which have been reported in the literature in the context of WM tasks (e.g., Gevins, Smith, McEvoy, \& Yu, 1997; Jensen \& Tesche, 2002; McEvoy, Pelloucoud, Smith, \& Gevins, 2001; Schack, Vath, Petsche, Geissler, \& Moller, 2002). Additional support for this interpretation stems from the finding that both theta power (Bastiaansen et al., 2002a) and theta coherences (Weiss et al., 2001; reviewed in Weiss \& Müller, 2003) increase over frontal electrodes during the course of sentence processing. Furthermore, Weiss et al. (2001) showed that frontal theta coherences were larger when subjects read object-relative clauses, which are considered to impose a high demand on verbal WM, as compared to the less demanding subject-relative clauses. Finally, the presence of a frontal theta component following both open-class words and closed-class words occurring in a sentence context (Bastiaansen et al., 2005) is compatible with a verbal WM interpretation of this component.

Another tentative alternative interpretation of the frontal theta increase is based on the notion that syntactic and semantic violations both constitute an error compared to a correct sentence. Both violation types induce a frontal theta increase. Therefore an interpretation of this effect in terms of error monitoring also seems viable. In this context, it is interesting to note that the frontal theta increases that we observe may be related to the error-related negativity (ERN, Falkenstein, Hohnsbein, Hoormann, \& Blanke, 1991; Gehring, Goss, Coles, Meyer, \& Donchin, 1993), an ERP component that can be observed when subjects make erroneous responses. A recent frequency-domain analysis of the ERN has shown that it largely consists of a theta oscillation with a frontal midline distribution that is phase-locked with respect to the response (Luu \& Tucker, 2001). Combining this finding with our language-related frontal theta effects, one could hypothesize the existence of a general error detection mechanism that involves frontal theta 
increases, of which the phase-locked, response-related ERN is a special case. In this framework, the different lateralizations (left or right-hemisphere dominance for syntactic violations, and a midline distribution for semantic violations) that we observed in response to semantic and syntactic violations occurring in a sentence context then may reflect domain-specific processes that are overlaid upon this general error detection mechanism.

\subsection{Gamma power changes}

The gamma component represents one of the first reports of gamma power changes during online sentence processing. Previous studies reporting on gamma power increases during language processing have either exclusively used isolated words for stimulus material (Pulvermüller, 1996, 2000), or computed gamma coherence during sentence processing (Weiss, Rappelsberger, Schack, \& Müller, 2003). Compared to a pre-stimulus baseline, the gamma power increase is restricted to right frontal areas, and it is fairly small (around 10\% power increase on average). However, when comparing gamma power changes between the two conditions it is striking that processing correct sentences induces larger gamma power over a large number of electrodes than processing sentences containing semantic violations. This suggests that (increases in) oscillatory activity in the gamma frequency range are part of the normal pattern of neural activity occurring during language processing. Apparently, the process that leads to this gamma increase is disrupted upon the occurrence of a semantic violation in the sentence. This suggests that disruption of normal, ongoing sentence processing is accompanied by an abrupt abolishment of gamma oscillations. This tentative interpretation fits with the results of a recent study in which gamma coherence was compared during the processing of correct sentences and sentences with a semantic violation (Weiss et al., 2003). In this study, processing correct sentences was associated with higher gamma coherence between parietal electrode sites than processing of semantic violations. In combination with the findings from the Weiss et al. study (2001), the present data suggest a functional role for gamma in normal sentence processing. Future experiments will have to further specify the exact nature of this functional role.

In conclusion, the present findings show a differential reactivity of both theta and gamma oscillations during language comprehension. At this early stage of research on the role of oscillatory brain dynamics in language comprehension, any interpretation of the data is tentative. However, at this time one can speculate that the modulations in oscillatory activity in the theta frequency range (both in terms of power changes, which reflect changes in local synchrony, and in terms of coherence changes, which reflect changes in long-range synchrony) may be instrumental in performing some of the basic cognitive functions needed during language processing, such as semantic retrieval and verbal WM, and may possibly reflect activity of a general error detection mechanism when a semantic or syntactic violation is encountered. The existence of both power and coherence increases of gamma oscillations during the processing of correct sentences, and the absence, or at least reduction of these increases when a semantic violation is encountered, suggests an involvement of gamma in normal language processing, the exact nature of which has yet to be established.

The combined results of experiments that have addressed oscillatory brain dynamics during language comprehension suggest that oscillatory activity in both low and high frequency ranges may play a role in binding together the different 'nodes' of the language processing network. Further study of these oscillatory brain dynamics will lead to a more precise characterization of how such functional networks are coupled and uncoupled such that the reader/listener perceives the linguistic input stream in a meaningful and integrated manner. This will eventually lead to a better understanding of the neurophysiological basis of language comprehension.

\section{Acknowledgments}

The authors thank Nicole Wicha, Dirk Janssen, Thomas Urbach, and two anonymous referees for their helpful comments on an earlier version of this paper, and Eric Maris for advice regarding the statistical analysis of the data. At the time of manuscript preparation, M.B. was supported by a VENI grant from the Dutch Organization for Scientific Research (NWO) and L.H. was supported by post-doctoral fellowship from the National Institute of Health (NIH 5-T32DC00041-10).

\section{Appendix A}

Full set of stimulus materials utilized. Original Dutch version and English gloss translation. For each sentence, the critical words are in capital letters, the first is the semantic violation and the second is the coherent control sentence.

1. De stad Amsterdam is heel OUD/DUN en mooi. The city Amsterdam is very old/thin and beautiful.

2. Einstein was een persoon die SLIM/BEWOLKT en innoverend was.

Einstein was a person that smart/cloudy and innovative was.

3. Een Delft's tegeltje is aardewerk dat BLAUW/SNEL en wit is. A Delft's small tile is earthenware that blue/fast and white is.

4. De stad Venetië heeft heel veel GRACHTEN/GEDACHTEN en mooie gebouwen. 
The city Venice has very many canals/thoughts and beautiful buildings.

5. Vanillevla is een dessert dat GEEL/SLIM en zoet is.

Vanilla 'vla' is a dessert that yellow/smart and sweet is.

6. Het milieufront helpt bedreigde diersoorten zoals de WALVIS/ TELEFOON of de reuzenpanda.

The environmental groups help threatened animals such as the whale/telephone or the Giant Panda.

7. Saoedi-Arabië is een land dat RIJK/ROMIG en droog is. Saudi Arabia is a country that rich/creamy and dry is.

8. Australië is een land dat heel GROOT/ZWAAR is.

Australia is a country that very large/heavy is.

9. Zeeland is een provincie met veel STRANDEN/DROMEN en water.

Zeeland is a province with many beaches/dreams and water.

10. Stamppot is een maaltijd die bestaat uit AARDAPPELS/KURK en groenten.

Stamppot is a main dish that 'is made from' potatoes/cork and vegetables.

11. Het bedrijf Philips maakt veel LAMPEN/ANTWOORDEN en radio's.

The company Philips makes many lamps/answers and radios.

12. Spanje is een land met veel ZON/GRATEN en stranden Spain is a country with much(many) sun/fish bones and beaches.

13. Longkanker is een kwaal die gewoonlijk FATAAL/VERLEGEN is. Lung cancer is a disease that usually fatal/shy is.

14. Sesamstraat is een programma voor PEUTERS/BLOEMEN en kleuters.

Sesame Street is a program for toddlers/flowers and infants.

15. De Noordpool is een gebied dat heel KOUD/SOEPEL is. The North Pole is an area that very cold/flexible is.

16. De Egyptische piramides zijn gebouwen die OUD/ SMAKELIJK zijn.

The Egyptian pyramids are buildings that old/savory are.

17. De meeste gebouwen in Rotterdam zijn HOOG/VERLIEFD en modern.

The common/most buildings in Rotterdam are high/in love and modern.

18. Het bedrijf Microsoft maakt SOFTWARE/MILIEU en hardware.

The company Microsoft makes software/environment and hardware.

19. Traditionele spaghetti bolognese bestaat uit spaghetti met GEHAKT/BEHANG en tomatensaus.

Traditional spaghetti Bolognese consists of spaghetti with ground beef/wallpaper and tomato sauce.

20. De Nederlandse treinen zijn GEEL/ZUUR en blauw.

The Dutch trains are yellow/sour and blue.

21. De stad Utrecht heeft een grote TOREN/TROUW en grachten. The city Utrecht has a large tower/fidelity and canals.

22. Speculaas wordt meestal in de vorm van een MOLEN/INVAL of een pop gemaakt.

[Type of cookie] is usually in the shape of a mill/attack or a puppet made.

23. Vergeleken bij andere drop smaakt muntdrop ZOET/LAAT en hard.

Compared to other types licorice does taste coin licorice sweet/late and hard.

Compared to other types of licorice, coin licorice is sweet/late and hard.

24. De universiteit van Leiden is de OUDSTE/DIEPSTE in Nederland.

The University of Leiden is the oldest/deepest in the Netherlands.

25. Hagelslag strooi je op BROOD/GELUID of beschuit. Chocolate confetti put you on bread/sound or crackers.

26. De bedrijven Gazelle en Batavus maken FIETSEN/WOLKEN en fietstassen.
The companies Gazelle and Batavus make bicycles/clouds and bicycle accessories.

27. Mazelen is een ziekte die vooral KINDEREN/STENEN treft. Measles is a disease that mainly children/stones affects.

28. Nederland is een land met veel KOEIEN/METAFOREN en schapen.

The Netherlands is a country with many cows/metaphors and sheep.

29. Zo'n tweeduizend jaar geleden werd Caesar benoemd tot KEIZER/BOOM van Rome.

About 2000 year ago was Caesar named [to be] king/bomb of Rome.

30. Wim Kok is een politicus en hij is de PREMIER/VIS van Nederland.

Wim Kok is a politician and he is the prime minister/fish of the Netherlands.

31. Bill Clinton is een man met veel ervaring in REGEREN/VLOEIEN en reizen.

Bill Clinton is a man with many experience in governing/flooding and travel.

Note 'vloeien' is a way of moving specific to liquids.

32. Beethoven componeerde in dat jaar muziek voor PIANO/ ENVELOP en viool.

Beethoven composed in said year music for piano/envelope and violin.

33. Pinoccio was een jongen die een hele lange NEUS/MENING had. Pinocchio was a boy who a very long nose/opinion had.

34. Nederland is een land dat VLAK/KLEVERIG en groen is. The Netherlands is a country that level/sticky and green is.

35. Sinterklaas is een man die heel AARDIG/HOBBELIG is. [Santa Claus] is a guy who very friendly/bumpy is.

36. Luxemburg is een land dat heel KLEIN/HARIG is. Luxembourg is a country that very small/hairy is.

37. Albert Heijn is een supermarkt die in Nederland heel BEKEND/ VERLIEFD is.

[Local chain] is a supermarket that in the Netherlands very wellknown/in love is.

38. Nijntje is een wit KONIJN/IDEE met lange oren. [Cartoon character] is a white rabbit/idea with long ears.

39. Ganzenbord is een spel dat leuk is voor KINDEREN/TOMATEN en volwassenen.

[game] is a game that nice is for children/tomatoes and adults.

40. In de Hema koop je vooral ONDERGOED/WOLKEN en beddengoed.

At the [local chain] to buy you mainly underwear/clouds and bed linens.

41. Aristoteles is een bekende man die invloed op de FILOSOFIE/ HEMEL had.

Aristotle is a well-known man who influence on the philosophy/ heavens had.

42. Het bedrijf BMW maakt AUTO'S/VERLANGENS en motoren. The company BMW creates cars/desires and motorcycles.

43. In Australië eet men vlees van KANGOEROES/BANKEN of krokodillen.

In Australia to eat one meat of kangaroos/banks or crocodiles.

44. De Nijmeegse Vierdaagse is een gebeurtenis waarbij mensen vier dagen LOPEN/BESTUIVEN en feesten.

The Nijmegen four days is a festival at which people four days walk/pollinate and party.

45. De Rijn loopt door Nederland en komt in de NOORDZEE/ BEROERTE uit.

The Rhine goes through the Netherlands and ends in the North Sea/stroke in.

46. Pino is een grote vogel met blauwe/bezielde VEREN en een oranje snavel.

[Big Bird] is a big bird with blue/enchanted feathers and a orange beak.

NOTE: Big bird is called Pino in Holland, and he is blue, not yellow. 
47. Spa is een drank bestaande uit WATER/GEDRAG met bubbeltjes. [Brand name like Perrier] is a drink consisting of water/behavior and bubbles.

48. Roodkapje wordt opgegeten door een WOLF/STEEN en gered door de jager.

Little Red Riding Hood is eaten by the wolf/stone and saved by the huntsman.

49. 's Ochtends is de Graafseweg heel DRUK/GELOVIG en lawaaierig.

In the morning is the [major street] very busy/religious and noisy.

50. Op vijf december snoepen veel kinderen van hun letter van CHOCOLA/ MIST en pepernoten.

On fifth of December to munch many children on their letter made of chocolate/ mist and [candy].

NOTE: This is the Sint Nicolaas day, on which children receive treats, often in the shape of the first letter of their name.

51. Nasi goreng is een maaltijd die je maakt van RIJST/IRONIE en kruiden.

Nasi goreng is a meal that one makes with rice/irony and herbs.

52. De Marlboro cowboy rookt altijd een SIGARET/THEEPOT op zijn paard.

The Marlboro cowboy smokes always a cigarette/teapot on his horse.

53. Omo is een bekend wasmiddel voor KLEREN/BRIEVEN en lakens.

[Brand name] is a well-known detergent for clothes/letters and sheets.

54. Drenthe is een kleine PROVINCIE/STEMMING in Nederland. Drenthe is a small province/opinion of the Netherlands.

55. Friesland is een provincie waar veel mensen ZEILEN/BLINKEN en schaatsen.

Friesland is a province in which many people sail/blink and ice skate.

56. In de sportwereld is Johan Cruijf een bekende VOETBALLER/ INKTVIS en trainer.

In the world of sports is Johan Cruijf a well-known football player/octopus and trainer.

57. De serie Baywatch speelt op een STRAND/RAAM in een zonnig land.

The series Baywatch is situated on a beach/window in a sunny country.

58. André Hazes is beroemd geworden door zijn LIEDJES/DAGEN en zijn optredens.

[Singer] has well-known become from his songs/days and his performances.

59. John Cleese is bekend geworden doordat hij erg GRAPPIG/ VOCHTIG is.

John Cleese has well-known become because he very funny/ damp is.

60. Ajax is een landelijke CLUB/WRAT die in Amsterdam speelt. [football club] is a country wide club/wart that in Amsterdam has its home.

61. In de winkel Aldi kun je je boodschappen GOEDKOOP/GEESTELIJK doen.

In the store [local chain] can one his groceries cheap/spirited(religiously) buy.

62. Popeye wordt heel sterk van het eten van SPINAZIE/BENZINE uit blik.

Popeye becomes very strong from the eating of spinach/gasoline from can.

63. In het sprookje moet Doornroosje honderd jaar SLAPEN/ STROMEN na een toverspreuk.

In the fairytale has to Sleeping Beauty one hundred years sleep/ stream after a spell.

NOTE: 'stromen' can only be done by liquids.

64. Assepoester verliest haar glazen MUILTJE/IDEE op weg naar huis.

Cinderella loses her glass slipper/idea on her way to home.
65. In het huis van Sneeuwwitje leefden zeven DWERGEN/MENINGEN met grappige namen.

In the house of Snow White lived seven dwarfs/opinions with funny names.

66. De voetballer Maradonna vervulde de rol van SPITS/JURK in het Braziliaanse team.

The football player Maradonna played the role of forward/dress on the Brazilian team.

67. DVD is een nieuwe technologie voor het afspelen van FILMS/ WENSEN op de televisie.

DVD is a new technology for playing of movies/wishes on television.

68. In de show Big Brother leven twaalf mensen in een HUIS/THEEPOT zonder privacy.

In the show Big Brother to live twelve people in a house/teapot without privacy.

69. In het Wielermeer wordt veel gezwommen in de ZOMER/KEUKEN en het voorjaar.

In the [local lake] there is lots of swimming in the summer/kitchen and the spring.

70. Elvis Presley was een beroemde kunstenaar vanwege zijn MUZIEK/ GEESTEN en zijn dansen.

Elvis Presley was a well-known artist for his music/ghosts and his dancing.

71. Een patatje speciaal eet je meestal uit een ZAKJE/GEVAAR van papier.

A french fries [special] to eat one most often from a paper bag/ danger of paper.

72. De wereldatlas bevat van ieder land een KAART/PLANEET en wat informatie.

The world atlas contains of each country a map/planet and some information.

73. Met vijf gulden koop je makkelijk een STOKBROOD/WATERSNOOD in Friesland.

With five guilders to buy one easily a baguette/flood disaster in Friesland.

74. Winnie de Poeh snoept het liefst HONING/HOUT uit een pot. Winnie-the-Pooh munches [the] most favorite honey/wood from a jar.

75. Nelson Mandela werd na jarenlange opsluiting ineens PRESIDENT/KOELKAST van Zuid-Afrika.

Nelson Mandela was after a very long imprisonment suddenly president/refrigerator of South Africa.

76. Oude kaas smaakt heel erg PITTIG/PAARS en zout.

Old cheese tastes like very much savory/purple and salt.

77. De maan werd in 1969 bereikt met een AMERIKAANSE/ GEBAKKEN raket en bemanning.

The moon was in 1969 reached by an American/fried rocket and crew.

78. De firma Nike plaatst reclame op de KLEDING/FEESTDAGEN van veel sporters.

The company Nike places advertisement on the clothes/holidays of many sportsmen.

79. De Chinese keuken gebruikt in bijna alle gerechten RIJST/ GELUK of noedels.

The Chinese kitchen makes use of in almost all dishes rice/happiness or noodles.

80. In Frankrijk drinkt men bij het eten altijd WIJN/VREDE en water.

In France to drink one at [the] dinner always wine/peace and water.

81. Voor de operatie waste de dokter zijn HANDEN/LONGEN met zeep.

Before the operation to wash the doctor his hands/lungs with soap.

82. De Everest is een berg die heel HOOG/DEMENT is.

The Everest is a mountain that very high/demented is. 
83. Nijmegen is een van de OUDSTE/ZOUTSTE steden van Nederland.

Nijmegen is one of the oldest/saltiest cities in the Netherlands.

84. De Sahara is een plaats die heel DROOG/VLOEIBAAR en heet is. The Sahara is a place that very dry/fluid and hot is.

85. Haring is een vis die je vindt in ZOUT/ZUUR water zoals de Noordzee.

Herring is a fish that you find in salty/sour water like the North Sea.

86. McDonalds is een Amerikaans RESTAURANT/OOR dat over de hele wereld verspreid is.

McDonalds is an American restaurant/ear that over the whole world to be found is.

87. In de herfst verliezen de bomen BLADEREN/RAMEN en takken. In the autumn to lose the trees leaves/windows and branches.

88. In de meeste kerken zitten de mensen in BANKEN/VOGELS voor het altaar.

In [the] most churches to sit the people on benches/birds in front of the altar.

89. Zes weken voor Pasen vieren veel mensen CARNAVAL/GRAS in Limburg.

Six weeks before Easter celebrate many people Mardi Gras/ grass in [province].

90. De schrijver Shakespeare schreef veel SONNETTEN/JASJES en toneelstukken.

The writer Shakespeare wrote many sonnets/coats and plays.

91. De val van de Berlijnse Muur herenigde DUITSLAND/ GEWICHT en bracht veel verandering.

The fall of the Berlin Wall reunited Germany/gravity and brought on many changes.

92. In Nederland betaalt men vanaf volgend jaar met de EURO/ SNEEUW voor zijn boodschappen.

In the Netherlands to pay one from next year with the Euro/snow for your groceries.

93. De ziekte BSE besmet KOEIEN/TAFELS en kan misschien overgaan op mensen.

The illness [Mad cow disease] affects cows/tables and could maybe transmit to humans.

94. De Gouden Gids is handig voor het vinden van ADRESSEN/ HUMEUREN en namen.

The Yellow Pages is practical for the finding of addresses/tempers and names.

95. De zeemeermin is een schepsel dat je aantreft in SPROOKJES/ ADVIES en fantasie.

The mermaid is a creature that one finds in fairytales/advice and fantasy.

96. Veel mensen kopen biologische groenten omdat die GEZOND/ BOOS zijn en lekker smaken.

Many people to buy biological produce because that healthy/ angry is and good to taste.

97. Computers worden elk jaar SNELLER/BLIJER en kleiner. Computers get each year faster/happier and smaller.

98. Ikea is een warenhuis met veel MEUBELS/REGEN en andere dingen voor huizen.

Ikea is a warehouse with lots of furniture/rain and other things for houses.

99. Nijmeegse stadsbussen rijden op GAS/WATER of diesel. Nijmegen city busses run on natural gas/water or diesel.

100. De meeste Nederlanders spreken naast Nederlands ook ENGELS/RIJST of Duits.

The most Dutchmen speak next to Dutch also English/rice or German.

101. Kinderen beginnen op zesjarige leeftijd te LEZEN/ONTSTAAN en te schrijven.

Children start to at six years [of] age to read/exist and to write.

102. De laatste verkiezingen voor president in de V.S. waren VERWARREND/ VETTIG en lang.
The most recent elections for president in the USA were confusing/greasy and long.

103. Duitse glühwein is een warme DRANK/LES die je 's winters drinkt. German [hot wine] is a warm drink/class that one in the winter drinks.

104. New York is een plaats die vroeger een Nederlandse KOLONIE/ KOMKOMMER was.

New York is a place that historically a Dutch colony/cucumber was.

105. Snoopy is een cartoon van een witte HOND/AANVAL die veel vrienden heeft.

[Peanuts] is a cartoon of a white dog/attack that many friends has.

106. Mensen kunnen door de tunnel onder het Kanaal van ENGELAND/BOOMTOPPEN naar Frankrijk reizen.

People can through the tunnel under the English Channel of England/treetops to France travel.

107. Het schaap Dolly was het eerste dier dat een KLOON/HORLOGE was.

The sheep Dolly was the first animal that a clone/watch was.

108. De Smurfen zijn kleine blauwe WEZENS/KEUZES die samen in een dorp wonen.

The Smurfs are little blue creatures/choices that together in a village live.

109. Vergeleken met een gulden is een kwartje KLEINER/LIEVER en minder waard.

Compared to the guilder is a quarter smaller/sweeter and less worth.

110. De meeste mensen in Spanje vinden een siësta heel NORMAAL/ KLEVERIG en plezierig.

The most people in Spain think a siesta very usual/sticky and pleasurable.

111. AIDS is een ziekte die zich verspreidt via BLOED/BIDDEN en sexuele contacten.

AIDS/HIV is a disease that [itself] spreads via blood/prayer and sexual contact.

112. Sigmund Freud is bekend als PSYCHIATER/VUURPIJL in Wenen.

Sigmund Freud is well-known as [a] psychiatrist/rocket(firework) in Vienna.

113. De ramp in Tsjernobiel kwam door een nucleaire EXPLOSIE/ DANS in 1986.

The disaster in Chernobyl was caused by a nuclear explosion/ dance in 1996.

114. Jozef Stalin was een zeer invloedrijke DICTATOR/OCEAAN in de twintigste eeuw.

Jozef Stalin was a very influential dlictator/ocean in the twentieth century.

115. De Mona Lisa is een schilderij met daarop een VROUW/PAUZE met een glimlach.

The Mona Lisa is a painting with on it a woman/break with a smile.

116. Koningin Beatrix is een vrouw die zeer RIJK/VLOEIBAAR is en veel reist.

Queen Beatrix is a woman who very rich/fluid is and much travels.

117. Rembrandt is een schilder die BEROEMD/GEKOCHT en geliefd is. Rembrandt is a painter who famous/bought en loved is

118. Stroopwafels zijn koekjes die ROND/LEEG en lekker zijn. [cookies] are cookies that round/empty and tasty are.

119. Veganisten dragen nooit schoenen van LEER/ZAND of bont. Vegans to wear never shoes made of leather/sand or fur.

120. Mars is een planeet die ROOD/VIERKANT is. Mars is a planet that red/square is.

\section{References}

Baayen, R. H., Piepenbrock, R., \& van Rijn, H. (1993). The CELEX Lexical Database (CD-ROM). Philadelphia: University of Pennsylvania. 
Bastiaansen, M. C., \& Brunia, C. H. M. (2001). Anticipatory attention: An event-related desynchronization approach. International Journal of Psychophysiology, 43, 91-107.

Bastiaansen, M., \& Hagoort, P. (2003). Event-induced theta responses as a window on the dynamics of memory. Cortex, 39, 967-992.

Bastiaansen, M. C., van Berkum, J. J., \& Hagoort, P. (2002a). Eventrelated theta power increases in the human EEG during online sentence processing. Neuroscience Letters, 323, 13-16.

Bastiaansen, M. C., van Berkum, J. J., \& Hagoort, P. (2002b). Syntactic processing modulates the theta rhythm of the human EEG. Neuroimage, 17, 1479-1492.

Bastiaansen, M., Van der Linden, M., ter Keurs, M., Dijkstra, T., \& Hagoort, P. (2005). Theta responses are involved in lexico-semantic retrieval during language processing. Journal of Cognitive Neuroscience, $17(3), 1-12$.

Brown, C. M., \& Hagoort, P. (1999). On the electrophysiology of language comprehension: Implications for the human language system. In M. Crocker, M. Pickering, \& C. Clifton Jr. (Eds.), Architectures and Mechanisms for Language Processing (pp. 213237). Cambridge: Cambridge University Press.

Bullock, T. H. (1992). Introduction to induced rhythms, a widespread, heterogeneous class of oscillations. In E. Baçar \& T. H. Bullock (Eds.), Induced Rhythms in the Brain (pp. 1-26). Boston: Birkhäuser.

Burgess, A. P., \& Ali, L. (2002). Functional connectivity of gamma EEG activity is modulated at low frequency during conscious recollection. International Journal of Psychophysiology, 46, 91-100.

Chao, L. L., Nielsen-Bohlman, L., \& Knight, R. T. (1995). Auditory event-related potentials dissociate early and late memory processes. Evoked Potentials-Electroencephalography and Clinical Neurophysiology, 96, 157-168.

Falkenstein, M., Hohnsbein, J., Hoormann, J., \& Blanke, L. (1991). Effects of crossmodal divided attention on late ERP components. II. Error processing in choice reaction tasks. Electroencephalography and Clinical Neurophysiology, 78, 447-455.

Fell, J., Klaver, P., Lehnertx, K., Grunwald, T., Schaller, C., Elger, C. E., \& Fernandex, G. (2001). Human memory formation is accompanied by rhinal-hippocampal coupling and decoupling. Nature Neuroscience, 4, 1259-1264.

Foxe, J. J., Simpson, G. V., \& Ahlfors, S. P. (1998). Parieto-occipital$10 \mathrm{~Hz}$ activity reflects anticipatory state of visual attention mechanisms. Neuroreport, 9, 3929-3933.

Friederici, A. D., Pfeifer, E., \& Hahne, A. (1993). Event-related brain potentials during natural speech processing: effects of semantic, morphological, and syntactic violations. Cognitive Brain Research, 1, 183-192.

Fries, P., Reynolds, J. H., Rorie, A. E., \& Desimone, R. (2001). Modulation of oscillatory neuronal synchronization by selective visual attention. Science, 291, 1560-1563.

Gehring, W. J., Goss, B., Coles, M. G. H., Meyer, D. E., \& Donchin, E. (1993). A neural system for error detection and compensation. Psychological Science, 4, 385-390.

Gevins, A., Smith, M. E., McEvoy, L., \& Yu, D. G. (1997). High-resolution EEG mapping of cortical activation related to working memory: Effects of task difficulty, type of processing, and practice. Cerebral Cortex, 7, 374-385.

Hagoort, P., Brown, C., \& Groothusen, J. (1993). The syntactic positive shift (SPS) as an ERP measure of syntactic processing. Language and Cognitive Processes, 8, 439-483.

Hagoort, P., \& Brown, C. (1999). The Neurocognition of Language. Oxford: Oxford University Press.

Jensen, O., \& Tesche, C. D. (2002). Frontal theta activity in humans increases with memory load in a working memory task. European Journal of Neuroscience, 15, 1395-1399.

Kahana, M. J., Sekuler, R., Caplan, J. B., Kirschen, M., \& Madsen, J. R. (1999). Human theta oscillations exhibit task dependence during virtual maze navigation. Nature, 399, 781-784.
Kalcher, J., \& Pfurtscheller, G. (1995). Discrimination between phaselocked and non-phase-locked event-related EEG activity. Electroencephalography and Clinical Neurophysiology, 94, 381-384.

Klimesch, W. (1999). EEG alpha and theta oscillations reflect cognitive and memory performance: a review and analysis. Brain Research Reviews, 29, 169-195.

Klimesch, W., Doppelmayr, M., Stadler, W., Pollhuber, D., Sauseng, P., \& Rohm, D. (2001). Episodic retrieval is reflected by a process-specific increase in human electroencephalographic theta activity. Neuroscience Letters, 302, 49-52.

Klimesch, W., Russegger, H., Doppelmayr, M., \& Pachinger, Th. (1998). A method for the calculation of induced band power: Implications for the significance of brain oscillations. Electroencephalography and Clinical Neurophysiology, 108, 123-130.

Kutas, M., \& Hillyard, S. A. (1980). Reading senseless sentences: Brain potentials reflect semantic incongruity. Science, 207, 203-205.

Kutas, M., \& Van Petten, C. (1994). Psycholinguistics electrified: Event-related brain potential investigations. In M. Gernsbacher (Ed.), Handbook of Psycholinguistics (pp. 83-143). New York: Academic Press.

Luu, P., \& Tucker, D. M. (2001). Regulating action: Alternating activation of midline frontal and motor cortical networks. Clinical Neurophysiology, 112, 1295-1306.

Maris, E. (2004). Randomization tests for ERP topographies and whole spatiotemporal data matrices. Psychophysiology, 41(1), 142-151.

McClelland, J. L., StJohn, M., \& Taraban, R. (1989). Sentence comprehension: A parallel distributed approach. Language and Cognitive Processes, 4, 287-335.

McEvoy, L. K., Pelloucoud, E., Smith, M. E., \& Gevins, A. (2001). Neurophysiological signals of working memory in aging. Cognitive Brain Research, 11, 363-376.

Neville, H. J., Kutas, M., Chesney, G., \& Schmidt, A. L. (1986). Eventrelated brain potentials during initial encoding and recognition memory of congruous and incongruous words. Journal of Memory \& Language, 25, 75-92.

Neville, H., Nicol, J., Barss, A., Forster, K., \& Garrett, M. (1991). Syntactically based sentence processing classes: Evidence from eventrelated potentials. Journal of Cognitive Neuroscience, 3, 151-165.

Osterhout, L., \& Holcomb, P. J. (1992). Event-related potentials elicited by syntactic anomaly. Journal of Memory \& Language, 31, 785-806.

Osterhout, L., \& Mobley, L. A. (1995). Event-related brain potentials elicited by failure to agree. Journal of Memory and Language, 34, 739-773.

Pulvermüller, F. (1996). Hebb's concept of cell assemblies and the psychophysiology of word processing. Psychophysiology, 33, 317-333.

Pulvermüller, F. (2000). Distributed assemblies, high frequencies and the significance of EEG/MEG recordings. In R. Miller (Ed.), Time and the Brain (pp. 241-249). Amsterdam: Harwood.

Pulvermüller, F., Lutzenberger, W., \& Preissl, H. (1999). Nouns and verbs in the intact brain: Evidence from event-related potentials and high-frequency cortical responses. Cerebral Cortex, 9, 497-506.

Rodriguez, E., George, N., Lachaux, J., Martinerie, J., Renault, B., \& Varela, F. J. (1999). Perception's shadow: Long-distance synchronization of human brain activity. Nature, 397, 430-433.

Rugg, M. D. (1990). Event-related brain potentials dissociate repetition effects of high- and low-frequency words. Memory \& Cognition, 18, 367-379.

Schack, B., Vath, N., Petsche, H., Geissler, H. G., \& Moller, E. (2002). Phase-coupling of theta-gamma EEG rhythms during short-term memory processing. International Journal of Psychophysiology, 44, $143-163$

Schack, B., Weiss, S., \& Rappelsberger, P. (2003). Cerebral information transfer during word processing: Where and when does it occur and how fast is it. Human Brain Mapping, 19, 18-36.

Singer, W. (1993). Synchronization of cortical activity and its putative role in information processing and learning. Annual Review of Physiology, 55, 349-374. 
Singer, W. (1999). Neuronal synchrony: A versatile code for the definition of relations?. Neuron, 24, 49-65 pp. 111-125..

Smith, M. E., Stapleton, J. M., \& Halgren, E. (1986). Human medial temporal-lobe potentials-evoked in memory and language tasks. Electroencephalography and Clinical Neurophysiology, 63, 145-159.

Stuss, D. T., Picton, T. W., \& Cerri, A. M. (1986). Searching for the names of pictures Ò an event-related potential study. Psychophysiology, 23, 215-223.

Tallon-Baudry, C., \& Bertrand, O. (1999). Oscillatory gamma activity in humans and its role in object representation. Trends in Cognitive Science, 3, 151-162.

Tallon-Baudry, C., Bertrand, O., Delpuech, C., \& Pernier, J. (1996). Stimulus specificity of phase-locked and non-phase-locked $40 \mathrm{~Hz}$ visual responses in human. Journal of Neuroscience, 16, 4240-4249.

Taylor, W. L. (1953). "Cloze procedure: A new tool for measuring readability. Journalism Quarterly, 30, 415-433.

Tesche, C. D., \& Karhu, J. J. T. (2000). Anticipatory cerebellar responses during somatosensory omission in man. Human Brain Mapping, 9, 119-142.
Varela, F., Lachaux, J. P., Rodriguez, E., \& Martinerie, J. (2001). The brainweb: Phase synchronization and large-scale integration. Nature Reviews Neuroscience, 2, 229-239.

Weiss, S., \& Rappelsberger, P. (1996). EEG coherence within the 13$18 \mathrm{~Hz}$ band as a correlate of a distinct lexical organisation of concrete and abstract nouns in humans. Neuroscience Letters, 209, $17-20$.

Weiss, S., Rappelsberger, P., Schack, B., \& Müller, H. M. . (2003). Koharenz- und Phasenuntersuchungen und ihre Bedeutung fur die Untersuchung von Sprachprozessen. In G. R. H. M. Mueller (Ed.), Neurokognition der Sprache (pp. 211-258). Tubingen: Stauffenburg.

Weiss, S., \& Müller, H. M. (2003). The contribution of EEG coherence to the investigation of language. Brain \& Language, 85, 325-343.

Weiss, S., Müller, H. M., King, J. W., Kutas, M., \& Rappelsberger, P. (2001). EEG-coherence analysis of naturally spoken English relative clauses. Brain Topography, 13, 317.

Weiss, S., Müller, H. M., \& Rappelsberger, P. (2000). Theta synchronization predicts efficient memory encoding of concrete and abstract nouns. Neuroreport, 11, 2357-2361. 